Postula, M., \& Raczkowski, K. (2020). The Impact of Public Finance Management on Sustainable Development and Competitiveness in EU Member States. Journal of Competitiveness, 12(1), 125-144. https://doi.org/10.7441/joc.2020.01.08

\title{
THE IMPACT OF PUBLIC FINANCE MANAGEMENT ON SUSTAINABLE DEVELOPMENT AND COMPETITIVENESS IN EU MEMBER STATES
}

\section{- Marta Postula, Konrad Rac₹kowski}

\begin{abstract}
The social and economic policy pursued by national and European authorities is supported by the redistribution of public funds. Choices made by European member states regarding the relevant scale of redistribution should promote the individual nation's sustainable development and competitiveness. Increased capital and workforce flows strengthen so-called fiscal and spending competition, which weakens governments' capacity for running an autonomous fiscal policy. In EU countries, however, there are still quite significant differences between the basic parameters of fiscal and spending systems, indicating that governments are not as powerless as is often claimed. Further, the fact that elements of fiscal policy have consequences for a country's competitiveness should not be overlooked. Keeping this in mind, the main purpose of this article is to examine to what extent EU member states' public spending can have a real impact on changing performance indicators for goals related to competitiveness and sustainable development. To this end, an approach based on panel models (individual vs. random effects) verified with a Hausman specification test was used. Our findings demonstrate the significant impact of an active spending policy on the indicators selected for analysis, i.e. indicators related to the stable development and competitiveness of EU member states within the period of 2008-2018. Our research results have also shown that to measure competitiveness there is a need to integrate a number of varied economic, social and innovative factors to analyze the growth potential of a particular country. In turn, our model studies demonstrate that countries where the fiscal deficit is below 3\% of GDP can implement a sustainable development policy more effectively, thus promoting competitiveness, instead of the periodic shocks and budget cuts which accompany remedial processes and procedures to alleviate excessive deficits.
\end{abstract}

Keywords: public finance management, sustainable development, public expenditure, Maastricht deficit criterion, competitiveness

JEL Classification: H500, H570, H410

Received: August, 2019

1st Revision: January, 2020

Accepted: February, 2020 


\section{INTRODUCTION}

As shown by the experience of many countries, efficient public finance management determines economic success and contributes to maximising the effect of using available resources (Pretorius \& Pretorius, 2016). At the same time, functional tax policy, institutional and regulatory structures, along with the structure of public revenues and expenditures all have an impact on a given country's economy and can drive its growth and economic development (Stiglitz, 2000; Raczkowski, 2014). In this respect, established economic theories, including those regarding fiscal policy, were found wanting from a theoretical perspective. Indeed, the assumptions of the finance theory, and more specifically, E. Fama's market hypothesis (Fama \& French 2014), neoclassical assumptions as part of rational expectations theory, as well as monetarism and monetary policy have all proved dysfunctional. First of all, it has turned out that the market does not reflect all available information, and that new, even very advantageous information does not always or does not at all translate into inflation. Secondly, the rational expectations theory has failed, just as did adaptive expectations theory in the 1970s. Economic entities have never had access to full and unlimited information about the economic system in which they operate. They can merely speculate about the market and governmental decisions, at times influencing those decisions in accordance with population ecology theory (Raczkowski, 2015). Neither do they have information in regard to the prospects of an increase in the supply of money. Even a hypothetical quantitative easing by a given central bank, which enhances commercial bank liquidity as well as often increases concentration and exposure limits, by no means ensures greater bank credit creation in the economy as a whole.

These examples demonstrate that public finance management can indeed be run efficiently in clearly demonstrated ways unless political decisions prevail over the problems of the mounting public finance deficits and public debt levels. Irrespective of the research directed toward resolving this dispute within economic theory, it is desirable to focus attention on the economic policy actually implemented along with its outcomes for stable development, and thus to approach the problem relying on basic fiscal policy parameters related to the scale of GDP redistribution and to the growth rate achieved. These determinations must be undertaken while taking account of the policy's underlying qualitative factors related to social customs, procedures, legal regulations and their application. The choice of the adequate scale of redistribution, measured with the revenue- and expenditure-to-GDP ratio, and the achievement of the desirable growth rate represent the fundamental tasks for policymakers responsible for a given country's medium-term social and economic development, irrespective of the political factors involved.

The countries supported with measures undertaken by communities such as European Union, for example, as part of its initiatives (European Commission, 2018) seek to implement economic solutions based on sustainable development, a concept defined in social, economic and environmental terms (Elkington, 2004). It has been suggested that by 2030 cultural factors should be also included as the fourth sustainability component (Soini \& Birkeland, 2014; Nurse, 2006). In addition, sustainable development should take place on three action levels, i.e. individual, organisational and global (Donaires et al., 2019), with the commitment of each government to monitor sustainable activities taking place at the socio-economic level (Patora-Wysocka \& Sułkowski, 2019). It has also been concluded that as part of these actions, the objective of sustainable development must be supported 
by sustainability finance (Shrithongrung \& Kriz, 2014). Such real measures stem from the fact that a financial system is a component of an economic system consisting of two principal components: the public finance sector and the market-based finance system. Actions undertaken as part of the sustainability finance concept could contribute to re-orienting finance measures and to strengthening the efforts to generate a long-term positive impact on the socio-economic development. A particular role and importance in this respect is ascribed to public authorities, which use public finance to achieve sustainable development (Collignon, 2008). In considering efforts of public authorities to maintain public finance stability, attention should be devoted to the need for the public sector to always fulfil its principal functions (i.e. allocation, redistribution and stabilisation), and to thus prevent a long-term imbalance in the respective public finance system. This can be achieved by developing an effective public spending and revenue system for the public finance sector (Alegre, 2012; Postula, 2018). At the same time, the focus on sustainable development needs to be supplemented by a concentration on competitiveness as the essential condition of development to be achieved by economic policies (Tudos \& Rusu, 2015). In the case of the EU members, crucial roles have emerged for both innovation and education as determinants of EU competitiveness and economic convergence (Dima et al., 2018). According to Oprescu (2012), the achievement of profitable positions depends on variables such as performance, welfare systems, efficiency, innovation and sustainability. As previous (financial) and actual (migration) crisis policy debates took into great consideration the competitiveness issue (Kisielakova et al., 2019), it is now important to take this opportunity to improve the potential for sustainable long-term growth in Europe (Bock, 2017).

Previous research has proven significant interrelations among assessments of global competitiveness, business environment, and human development in and among the $28 \mathrm{EU}$ countries for the period of 2006-2017 using the data of the global competitiveness index (GCI), doing business index (DBI), and human development index (HDI), the latter of which is focused on the level of human development and potential as an important factor for the development and sustainability of a country (Kisielakova et al., 2019; Simionescu, 2016). Such a link has also been identified in the literature as highlighting the deep relationship between competitiveness and sustainable development, while at the same time demonstrating the necessity for more detailed studies in this area. (Balkyte \& Tvaronavicience, 2010).

Having established the clear link between competitiveness and the sustainability of a country, just exactly how public finance management affects these variables must be verified and closely examined.

The research problem presented in the paper focuses on analysing the actual impact on sustainable development, along with competitiveness issues influenced by public expenditures as reflected in current social and economic policy. The primary objective of the paper is to establish the extent to which the public expenditures of European Union member states can have a real impact on changing the performance indicators in terms of goals that encompass and enhance competitiveness and sustainable development. The secondary objective is to establish the correlation of those indicators with a country's compliance with the Maastricht public deficit criterion. The authors wish to examine to what extent the fact that respective countries' authorities maintain public deficit below 3\% of GDP influences the scale of public expenditure's impact on performance of selected sustainable development indicators. 
A mixed methodology combining the results of qualitative and quantitative research is used to empirically verify the hypotheses related to the research problem presented. The qualitative research is based on descriptive analysis, and the quantitative research will include the method of statistical information systemization, based on statistical source data analysis, static dependence methodology, including fixed effects and random effects panel models.

\section{PUBLIC FINANCE AS A MAJOR TOOL FOR BUILDING SUSTAINABLE DEVELOPMENT AND COMPETITIVENESS}

In retrospect, one can observe that at times of economic upturn, economic entities (financial institutions, enterprises) try to reduce the regulatory and controlling role of government, but when symptoms of crises arise, governments' measures consist in counteracting its consequences and in an interventionist stimulation of the economic growth. This was also the case when the crisis of the neoliberal system occurred, despite the financialisation of the global economy (Rambarran, 2015; Davidson, 2017). In the context of the currently growing role of government, it is of utmost importance that this process should rely on the public finance sector based on solid and transparent rules of play and managed by strong and active government whose economic policy is guided by an adequate paradigm to meet the contemporary challenges.

The scope of research into the effectiveness of the measures taken by the authorities of respective countries and communities (for example EU) is constantly widening, especially as a result of the crisis. The first stage of the last crisis manifested itself in the lack of:

- mechanisms to support business continuity through state involvement;

- international cross-border regulations;

- effective supervisory control;

- sufficient amount of subsidies from the state budget, and of government intervention in the required areas.

This is perfectly illustrated by the data presented by the European Commission, which reveal that general government assets in financial institutions increased in EU countries (EU-28) in total from EUR 150 million in 2008 to EUR 359,946 million in 2016. This means that banks operate much better when they comply with regulations and take proper advantage of both the opportunities offered by the regulatory framework and by the government capital support rather than when they achieve their "success" in the free market space. The political and social requirements focusing on sustainable development, financial stability and mitigating economic and social vulnerability call for new economic paradigms and efficient national and international institutions (Erhard, 2012; Gorynia \& Kowalski, 2008). In the forty years leading up to the crisis, economics has come closer to business science and business approach, which - as demonstrated in the previous sub-chapter - fails to address the current challenges (Rodrik, 2011). Preventive legislation which sets the effective course of action for the government and helps avert crises, as well as modified economic propositions and social expectations as to how government and public services should function, have become the main substance of political sciences, ushering in a yet stronger applicative discourse in economics. To find the way to make science reflect the proc- 
esses taking place in practice has become one of the key challenges of our time (Facchini \& Seghezza, 2018). When recession strikes, the attempts to enforce the economic policy criteria have demonstrated that neither the classical instrument used in economic policy, i.e. the government's fiscal policy itself, nor the use of other instruments, more of which are available than in previous crises, will suffice to mitigate its consequences. The crisis experienced by us showed that its burden cannot be overcome without the intervention of at least some central banks, which independently of government institutions - took measures that had consequences for the social and economic development. This way the public finance system became a bipolar system, and the government's fiscal policy was extended to include central bank's institutional system, which is consistent with this policy, , and on the other, it remains independent. As pointed out before government and central bank interventions undertaken as part of post-2007 crisis management were much stronger and much more far-reaching, which, as a result, led to a reorganisation of social sciences. In terms of crisis management, government has been given a stronger mandate to regulate and supervise markets in the institutional approach (Buch \& Dages, 2018). That is why the authorities, focused on keeping crisis from deepening and on efforts to achieve consolidation, also started to extensively use budgetary tools and financial market instruments as part of their measures aimed at balanced social development. The measures adopted: coordination, intervention and supervision over activities of business organisations may be effective only in the framework of well-organised and effective economic governance that strives to makes the best possible use of instruments of market intervention. In other words, a government's intervention may only be successful with transparent and efficient support of respective sectors of public finance, and with disciplined and controlled money markets. Effective tools help national and European authorities develop institutional and legal means that not only drive the economic growth but also level the income disparities that increased so much during the reign of neoliberal economics. As pointed out before, after the 2007-2008 crisis, there was no ready-made paradigm, trend of thought that could be implemented also with respect to government intervention (Abramov et al., 2016). Therefore, it became vital to search for a new economic paradigm offering new concepts derived from practical knowledge and from the processes taking place in the economy. As a matter of fact, it turned out it is no longer enough to use the existing instruments of active government involvement borrowed from various scientific disciplines such as descriptive law and "business approach" economics (Arrow, 2012; Hoover, 2015). As it happens, neither is it enough to apply the Keynesian approach that is based solely on intervention through public services and monetary flows thus injected into the economy, which have also become outdated categories. The inadequacy of these theories is due to a number of factors. One of them is, undoubtedly, the re-interpretation of the scale and scope state ownership should have. After several decades of predominance of pro-privatisation trend - especially in the CEE region - privatisation was halted, and one can even say the emphasis was put again on strengthening state ownership by buying some assets back or by those in power sending a clear message that such is the official course of the national policy. Actions like these confirm the crisis of globalisation that aims to liberalise the attendant integration of national economies markets, which used to function separately, into one interconnected worldwide market (Ivanová \& Čepel, 2018). Ever more opinions are voiced in the scientific discourse that criticise or at times even repudiate the contemporary global capitalism as a faulty, unfair and even inefficient system (Mazzucato, 2017). 
In this respect, competitiveness plays also a vital role in addressing presented challenges and conditions. Countries in order to be able to meet desired goals and expectations need to compete in global market, which consequently forces them to introduce appropriate competitiveness measures. As indicated by Bernard \& Boucher (2007), the main challenges of institutional competitiveness are as follows:

- attracting capital - major challenge to sustained economic development;

- mobilizing labour - to produce goods and services efficiently;

- reconciling earning and caring work - prime determinant of institutional competitiveness.

There are quite numerous papers dealing with competitiveness. The difficulty in characterising this concept entails a great number of existing definitions and results in many studies being undertaken. As national competitiveness is not a directly measurable economic category, it is hard to determine a hierarchy or to provide an objective definition. OECD (2015) defines competitiveness as a capacity, in this case, of a country for “(...) facing the international competition and ensuring, in a sustainable manner, a high return on the factors of production used and high employment". On the other hand, Irish National Competitiveness Council suggests that competitiveness means "a success in international markets resulting in an overall welfare increase (...); these markets include international flow of goods, capitals and services. Companies from respective countries compete in the international market of goods and services. Due to lower tariff barriers in the world trade, the latter keeps deepening and extending”. The above perspective on competitiveness highlights the role of entrepreneurs; according to the authors, government should help entrepreneurs by creating adequate conditions for investment and by building a competitive strategy. The World Bank Group also undertook to investigate the essence of national competitiveness of economies, where competitiveness is identified with productivity. A comparative advantage resulting, for example, from low costs of labour, is not tantamount to competitive advantage. World Bank's suggestion underlines the role of innovation in the understanding of economic competitiveness (Radło, 2008).

How widely the competitiveness could be measured is shown by the most significative research tool i.e. the Global Competitiveness Index (GCI). This index treats the competitiveness as a set of institutions, policies, and factors that determine the level of productivity of an economy (Kiselakova et al., 2019).

The GCI combines 114 indicators grouped into 12 pillars: institutions, infrastructure, macroeconomic environment, health and primary education, higher education and training, goods market efficiency, labour market efficiency, financial market development, technological readiness, market size, business sophistication, and innovation (Schwab, 2017).

Whether a given country will be characterised by a high national competitiveness depends on an active adaptation to changes taking place on business and technological markets, where the objective is to achieve a sustainable economic growth. In this context, the concept of competitiveness can be undoubtedly viewed from a broader perspective, one that includes the goals of stable social and economic development measured by the degree of completion of goals defined in this respect. 
Given that the productivity of the economy determines the level of prosperity it can achieve, new tools for measuring growth appear, such as the Inclusive Development Index (IDI) which ranks countries based on 12 key performance indicators of inclusive development.

The IDI extends the perspective beyond the GDP growth alone being based on three pillars:

- Growth and Development, including GDP per capita growth, labour force participation and productivity, and healthy life expectancy.

- Inclusion, including median household income, poverty, and two inequality measures and Intergenerational Equity and Sustainability, including adjusted net savings, demographic dependency ratio, public debt, and carbon intensity (Kiselakova et al., 2019).

Another major area where the state has an impact on real economy but also on the population's living standards is the scope and quality of services provided as part of public policies that address a hierarchy of human needs, and the scope of the necessary public goods to satisfy them. The trend of thought that relies on decentralisation, free market services and profit-maximisation management in public services has become quite off-target. A shift is taking place towards a higher importance of the active government model and the related new economic paradigm, i.e. centralisation, return to national property (by means of repurchase) and an approach that makes it mandatory to serve public welfare; this calls for a reflection on how to provide these services without them turning into processes that are inefficient in terms of the primary goal. The processes taking place in the European sphere, which are indicative of a partial adoption of welfare state and of the ensuing far-reaching state interference with economic life, may soon give rise to another trend of thought, one sparked by public finance rather than by financial markets. With the increasing role of the state, it is becoming ever more important to work out the right way to take decisions on how to allocate its resources and implement public service tasks, also taking account of the supranational nature of some measures that are already being taken, for example, in the European Union. First and foremost, however, as pointed out by a number of researchers (Stiglitz, 2003), the global phenomena occurring at present have not created - to date - any efficient system for coordinating economic policy with the implementation of public services that are of interest to all countries (Wolf, 2004). Hence, it is worth pondering whether - or rather how - to tackle problems that are likely to become ever more apparent in the decades to come. Environmental pollution, security concerns and migrations are processes that are bound to aggravate and no country will be capable of solving them on its own.

A number of factors drive the competiveness of the economy. From the macroeconomic perspective, these include the monetary and fiscal policy implemented in a given country in the context of global processes. In the past, the most common approach was to examine the real currency exchange rate by reference to monetary policy, price levels, interest rates, purchasing power and interest parity rather than to fiscal variables. However, competitiveness also plays a key role in the classical Mundell (1963), Fleming (1962) models used to analyze the effectiveness of taxes. In this model, an expansive monetary policy is effective as a stabilising instrument for volatile exchange rates, as it improves competitiveness and increases net exports, while fiscal policy is ineffective as lower competitiveness crowds out net exports. Meanwhile, Becker (2015), relying on earlier works by Buchholz (2016) and Artidiatun (2017), applied a public finance analysis relating 
to an excessive tax and subsidy burden - pioneered, by the way - to develop a model where the competition between interest groups defines the balance of the income distribution. When the government decides to offer protection, it will aim to choose effective (rather than efficient) ways to distribute the income through taxes or public spending. Becker argued that any protection involves deadweight losses. In "Competitive Government", Breton (1996) made a classification, a brief summary and a critical assessment of a number of more popular theories. All of them are in use and new are being created. Since most analyses are conducted principally in harmony with Breton's theory of competitive governments, which is used to analyze some possible impacts of economic globalisation on the efficiency of public sector providing goods and services, we will focus on a different approach in our deliberations.

\section{AIM, METHODOLOGY AND DATA USED IN THE RESEARCH}

Having in mind the above theoretical discussion, the suggested research problem of determining the degree of interrelation between European countries' spending policy and sustainable development and performance indicators within the European Union is very topical and can contribute to the creation of new economic trends that take account of this very aspect. The main goal of the research conducted, whose results are presented in this article, was to indicate to what degree EU Member States' public spending can have a real impact on changing performance indicators for goals related to competitiveness and sustainable development. The research hypothesis determined was that the European Union member states' spending policy can have a real impact on changing the performance indicators for sustainable development goals and impact on competitiveness, determined by the level of development and fiscal deficit above $3 \%$ of GDP, in particular.

To prove the hypothesis put forward at the beginning and taking account of the theoretical analysis conducted, a decision was made to include in the analysis all EU member states whose fiscal deficit to GDP ratio meets or exceeds the convergence criterion, and to divide them into two groups with respect to this criterion. This enabled conducting quantitative research to indicate how the spending policy implemented by national government can contribute to improved sustainable development indicators both in the countries that comply with the Maastricht deficit criterion and those that do not. For detailed analysis, four indicators were selected:

- People at risk of poverty or social exclusion by age and sex;

- Life expectancy by age and sex;

- Main GDP aggregates per capita - Percentage of EU27 (from 2019) total per capita (based on million euro, EU27 from 2019), current prices (hereinafter referred to as "Main GDP aggregates per capita");

- Municipal waste by waste management operations (kilograms per capita), which measure the level of achievement of sustainable and development goals (DSG).

Those indicators also contribute to competitiveness as described by Tudose \& Rusu (2015) in a particular ability to create wealth and high standard of living in a country with the lowest rate of unemployment. A decision was made to conduct the research using panel models with 
sustainable development indicators as dependent variables, and EU countries' public spending levels according to COFOG categories (The Classification of the Functions of Government) and subcategories as explanatory variables. The data variability analysis and estimation method using fixed and random effects panel models (individual vs. random effects) were used to conduct the research. As concerns the individual fixed effects model, the unit under test in the analyses conducted is an EU member state, which, by definition, causes the response variable to have significantly different values. The simplest assumption in panel models is the existence of fixed, unknown (not observable) but constant differences between countries. The available data from Eurostat databases was used for the analysis which, according to the authors, present the most objective and reliable data, spanning a sufficient time series for the analysis. Keeping in mind the availability of pooled cross-sectional and time-series data, the authors opted for the panel study method. Using panel samples to build econometric models helps take account of the variability of the entities analyzed and of the changes observed over time in individual objects, while ensuring data aggregation. Panel models with dummy variables and random variable decomposition were used as the research tool.

Hence, as a first step, fixed effects models were prepared to examine the causes of changes in European Union member states when it comes to public spending structure according to COFOG categories, and the level of SDG achievement expressed with metrics defined by the European Commission.

$y_{i t}=\mathrm{X}_{\mathrm{it}} \beta^{\prime}+\alpha_{\mathrm{i}}+\varepsilon_{\mathrm{it}}$

where: alpha is a constant individual effect for itch observation.

Meanwhile, in the random effects model, each country was assigned a random variable whose realisation accounts for individual effect in a given period. In the random effects model, individual effects are not identical in subsequent periods. As a result, individual effects are not treated as parameters and we do not estimate their values. Whereas in the fixed effects model, we were able to interpret individual effects as an individual absolute term, which is different for each unit but constant over time, in the random effects model, the individual effects can be interpreted as individual random components. An absolute term can be introduced into the model:

$y_{i t}=\gamma+\mathrm{X}_{\mathrm{it}} \beta^{\prime}+\nu_{\mathrm{i}}$

$v_{i}=\alpha_{\mathrm{i}}+\varepsilon_{\mathrm{it}}$

In addition, it is necessary to meet the assumption that explanatory variables and random component are independent from individual effects.

The limitation of the research conducted is deliberately opting out of separately examining competitive positions and competitive abilities of countries - which in itself could be the subject of separate research. The research presented focuses on macroeconomic aggregates of basic descriptive statistics for dependent variables for European Union countries according to the Maastricht deficit criterion (Table 1), omitting the microeconomic approach for the purposes of aggregate sustainable development and testing the ability to compete as part of stimulating economic growth through a broadly defined fiscal policy. 


\section{RESULTS AND DISCUSSION}

Taking account of the research methods adopted, as a first step, a variability analysis was conducted for response data, i.e. sustainable development indicators in European Union member states in a 10-year period. The statistics obtained, as presented in Table 2, clearly suggest a major variability among European countries as regards the value of those indicators, which, undoubtedly stems from the social development, the society's wealth and awareness, and from the priorities of the economic policy in place. Indeed, among the top priorities set in Europa 2020 strategy is the desirable nature of the European economic growth, which should be:

- smart (developing an economy based on knowledge and innovation),

- sustainable (promoting a more resource efficient, greener and more competitive economy),

- inclusive (fostering a high-employment economy delivering social and territorial cohesion).

Secondly, the goal of the strategy is indicated, i.e. a package (as the targets are interrelated) of five headline very specific quantitative targets relating to: employment level, R\&D outlays, environmental protection (energy use), education and poverty reduction. In the sphere of strategy implementation method, the main innovation introduced is the so-called European semester, which increases the effectiveness of Member State policy coordination. The concept of competitiveness is mentioned in the strategy mostly in the context of sustainable growth (priority number two) and flagship initiatives being part of this priority, i.e. "resource-efficient Europe” and „An industrial policy for the globalisation era" which is why this very aspect is analyzed.

Tab.1 - Basic descriptive statistics for dependent variables for European Union countries by

Maastricht deficit criterion. Source: own research

\begin{tabular}{|c|c|c|c|c|c|c|c|c|c|c|c|c|}
\hline \multirow{2}{*}{$\begin{array}{l}\frac{u}{0} \\
\frac{\text { ज }}{7} \\
>\end{array}$} & \multicolumn{2}{|c|}{ Observations } & \multicolumn{2}{|l|}{ Mean } & \multicolumn{2}{|l|}{ Std. Dev. } & \multicolumn{2}{|c|}{ coef. variance } & \multicolumn{2}{|l|}{ Min } & \multicolumn{2}{|l|}{ Max } \\
\hline & $\begin{array}{l}\text { FD } \\
<3 \% \\
\text { GDP }\end{array}$ & $\begin{array}{l}\text { FD } \\
>3 \% \\
\text { GDP }\end{array}$ & $\begin{array}{l}\text { FD } \\
<3 \% \\
\text { GDP }\end{array}$ & $\begin{array}{l}\text { FD } \\
>3 \% \\
\text { GDP }\end{array}$ & $\begin{array}{l}\text { FD } \\
<3 \% \\
\text { GDP }\end{array}$ & $\begin{array}{l}\text { FD } \\
>3 \% \\
\text { GDP }\end{array}$ & $\begin{array}{l}\text { FD } \\
<3 \% \\
\text { GDP }\end{array}$ & $\begin{array}{l}\text { FD } \\
>3 \% \\
\text { GDP }\end{array}$ & $\begin{array}{l}\text { FD } \\
<3 \% \\
\text { GDP }\end{array}$ & $\begin{array}{l}\text { FD } \\
>3 \% \\
\text { GDP }\end{array}$ & $\begin{array}{l}\text { FD } \\
<3 \% \\
\text { GDP }\end{array}$ & $\begin{array}{l}\text { FD } \\
>3 \% \\
\text { GDP }\end{array}$ \\
\hline Goal 1 & 196 & 122 & 21.45561 & 25.1418 & 5.97567 & 6.059332 & $27.85 \%$ & $24.10 \%$ & 12.2 & 14 & 46.3 & 45.3 \\
\hline Goal 2 & 193 & 126 & 127024.2 & 209710.8 & 177271.4 & 204372.6 & $139.56 \%$ & $97.45 \%$ & 6068 & 15151 & 670292 & 645940 \\
\hline Goal 3 & 193 & 126 & 78.58756 & 79.21587 & 3.063044 & 2.975619 & $3.90 \%$ & $3.76 \%$ & 70.6 & 71.7 & 83.4 & 83.5 \\
\hline Goal 4 & 238 & 126 & 10.27227 & 13.02937 & 5.016562 & 7.535729 & $48.84 \%$ & $57.84 \%$ & 4 & 3.9 & 41.2 & 39.3 \\
\hline Goal 5 & 213 & 118 & 7454.451 & 11596.25 & 10572.67 & 11380.27 & $141.83 \%$ & $98.14 \%$ & 193 & 990 & 42094 & 41030 \\
\hline Goal 6 & 99 & 71 & 90.00808 & 90.42535 & 11.30016 & 10.94725 & $12.55 \%$ & $12.11 \%$ & 66.9 & 60.6 & 100.1 & 100.1 \\
\hline Goal 7 & 193 & 126 & 55.97461 & 86.43889 & 77.6894 & 88.56008 & $138.79 \%$ & $102.45 \%$ & 4.1 & 4.3 & 327.5 & 319.7 \\
\hline Goal 8 & 216 & 126 & 119.4319 & 90.43254 & 73.47843 & 41.27192 & $61.52 \%$ & $45.64 \%$ & 22.5 & 25.5 & 336 & 176.8 \\
\hline Goal 9 & 215 & 126 & 9947.183 & 12194.78 & 17658.1 & 16710.8 & $177.52 \%$ & $137.03 \%$ & 37.726 & 84.882 & 99052.15 & 70014.21 \\
\hline $\begin{array}{l}\text { Goal } \\
10\end{array}$ & 196 & 122 & 4.54949 & 5.031967 & 1.033317 & 1.11513 & $22.71 \%$ & $22.16 \%$ & 3.3 & 3.2 & 7.8 & 7.4 \\
\hline $\begin{array}{l}\text { Goal } \\
11\end{array}$ & 213 & 125 & 497.3192 & 469.56 & 133.3393 & 95.99894 & $26.81 \%$ & $20.44 \%$ & 260 & 256 & 830 & 791 \\
\hline $\begin{array}{l}\text { Goal } \\
12\end{array}$ & 216 & 126 & 1.627455 & 1.633133 & 1.025385 & 0.932287 & $63.01 \%$ & $57.09 \%$ & .2756 & 0.3795 & 4.4385 & 4.4736 \\
\hline $\begin{array}{l}\text { Goal } \\
13\end{array}$ & 193 & 126 & 40.07306 & 59.41905 & 54.39549 & 58.91144 & $135.74 \%$ & $99.15 \%$ & 2.8 & 3.9 & 223.5 & 221.6 \\
\hline
\end{tabular}




\begin{tabular}{|l|l|l|l|l|l|l|l|l|l|l|l|l|}
\hline $\begin{array}{l}\text { Goal } \\
14 \mathrm{r}\end{array}$ & 105 & 55 & 11086.95 & 19440.62 & 20793.55 & 25891.91 & $187.55 \%$ & $133.18 \%$ & 0 & 0 & 129865 & 84404 \\
\hline $\begin{array}{l}\text { Goal } \\
15\end{array}$ & 125 & 66 & 0.057928 & 0.072424 & 0.054202 & 0.054614 & $93.57 \%$ & $75.41 \%$ & .01 & 0.01 & .267 & 0.209 \\
\hline $\begin{array}{l}\text { Goal } \\
16\end{array}$ & 194 & 122 & 12.90928 & 13.47705 & 4.502264 & 4.981217 & $34.88 \%$ & $36.96 \%$ & 3.4 & 4.8 & 27.8 & 30 \\
\hline
\end{tabular}

FD - Fiscal deficit

Goal 1 - No poverty

Goal 2 - Zero hunger

Goal 3 - Good health and well being

Goal 4 - Quality education

Goal 5 - Gender equality

Goal 6 - Clean water and sanitation

Goal 7 - Affordable and clean energy

Goal 8 -Decent work and economic growth

Goal 9 - Industry, innovation and infrastructure

Goal 10 - Reduced inequalities

Goal 11 - Sustainable cities and communities

Goal 12 - Responsible consumption and production

Goal 13 - Climate action

Goal 14 - Life below water

Goal 15 - Life on land

Goal 16 - Peace, justice and strong institutions

The analysis conducted demonstrated a discrepancy between metrics relating to each sustainable development goal selected for implementation and monitoring both for countries meeting the Maastricht deficit criterion and those in excessive deficit procedure. As regards the first area under analysis, i.e. efforts to eliminate poverty among European Union countries' citizens, and the indicator defined for that goal, People at risk of poverty or social exclusion by age and sex, it has been observed that the mean value of this indicator was 21.45 for the countries whose deficit was in compliance with the criterion, while it was much higher (25.14) in the other countries. For the countries with a lower deficit, the value of this indicator, i.e. the typical level, differed by 5.97 from the mean level, representing a variance (variability of $27.85 \%$ ). It is worth adding that for the countries compliant with the convergence criterion, the lowest value of People at risk of poverty or social exclusion by age and sex was 12.2, and the highest one was 46.3. Meanwhile, for the countries with a higher deficit, the value of this indicator, i.e. the typical level, differed by 6.05 from the mean level, representing a variance (variability of $24.10 \%$ ). It is worth adding that for the countries that are not compliant with the convergence criterion, the lowest value of People at risk of poverty or social exclusion by age and sex was 14 , and the highest one was 45.3. The results obtained indicate that countries can take measures to diminish the scale of poverty without the need for excessive spending that would cause them to generate excessive deficit. Such results are an excellent point of departure for quantitative reflections on the impact of public spending on such a state of affairs.

From the point of view of the above discussion and of a comprehensive approach to sustainable development, it is worth analysing the indicator relating to the third defined goal, namely the one measuring Life expectancy by age and sex, whose values in the countries compliant with deficit criterion was between 70 and 83.4 years of age while the mean value of this indica- 
tor in those countries was 78.58 , with a variability of $3.09 \%$. The indicator had similar values also in the countries with an excessive deficit as it stood at 71.6 to 83.5 years of age respectively, with the mean value of 79.21 and a variance of $2.97 \%$. In this case, it is hard to find a direct correlation with the amount of direct public transfers.

When talking of sustainable development, one cannot forget the Main GDP aggregates per capita, defined for the goal decent work and economic growth. The variability analysis conducted indicates very significant differences in this respect between the countries with a low fiscal deficit and those where its level exceeds the threshold. This indicator for the countries with a deficit below and above 3\% of GDP stands, respectively, at 22.5 and 25.5 (minimum values), and at 336 and 176.8. The results corroborated the theoretical proposition that it is worth stimulating economic growth with public spending though one needs to always bear in mind the stability of public finance (Friedman, 2005).

Another area analyzed in terms of sustainable development is Sustainable cities and communities, and the indicator developed by the European Commission, Municipal waste by waste management operations (kilograms per capita). Quantitative research revealed that the mean value of this indicator in the period analyzed was 497.32 for the countries where deficit is at the level compliant with the criterion, i.e. lower than $3 \%$ of GDP, while in other countries it was much lower (469.56). For the countries with a lower deficit, the value of this indicator, i.e. its typical level, differed by 133.34 from the mean level, representing a variance (variability of $26.81 \%$ ). It is worth pointing out that for the countries that are compliant with the convergence criterion, the lowest value of Municipal waste by waste management operations (kilograms per capita) was 260, and the highest one was 830. Meanwhile, for the countries where deficit is above the threshold, the value of that indicator, i.e. its typical value, differed by 95.99894 from the mean level, representing a variance (variability of $20.44 \%$ ). It is worth adding that in the countries that are not compliant with the convergence criterion, the lowest value of Municipal waste by waste management operations (kilograms per capita) was 256, and the highest one was 791 . The results obtained reveal that countries can take measures to diminish the scale of pollution without the need for excessive spending that would cause them to generate excessive deficit. Such results are an excellent point of departure for quantitative reflections on the impact of public spending on such a state of affairs.

The analysis of descriptive statistics of dependent variables for European Union countries according to compliance/non-compliance with the Maastricht fiscal deficit criterion indicated the accuracy of the research assumptions, becoming a legitimate point of departure for further quantitative research. As part of this research, models to measure the impact of general government spending on the sustainable development indicators analyzed were estimated.

Fixed effects models were used in the analysis as the impact of independent variables on a dependent variable is related to differences between countries. For the purposes of an extended analysis, Table 2 presents the impact of respective spending categories on the level of sustainable development indicators defined. 
Tab. 2 - Results of the fixed effects model on the following indicators: People at risk of poverty or social exclusion by age and sex; Life expectancy by age and sex; Main GDP aggregates per capita, Municipal waste by waste management operations (kilograms per capita). Source: own research

\begin{tabular}{|c|c|c|c|c|}
\hline Detail & $\begin{array}{l}\text { People at risk of } \\
\text { poverty or social } \\
\text { exclusion by age } \\
\text { and sex }\end{array}$ & $\begin{array}{l}\text { Life expectancy } \\
\text { by age and sex }\end{array}$ & $\begin{array}{l}\text { Main GDP } \\
\text { aggregates per } \\
\text { capita }\end{array}$ & $\begin{array}{l}\text { Municipal waste by } \\
\text { waste management } \\
\text { operations }\end{array}$ \\
\hline Defence & -169.51853 & 35.421764 & $959.44726^{* * *}$ & 502.21401 \\
\hline Economic Affairs & $-167.82994 *$ & $98.920178^{* * *}$ & $686.95189 * *$ & -673.56667 \\
\hline Education & $-225.34521 *$ & 55.765706 & $843.69071^{* *}$ & 780.79178 \\
\hline $\begin{array}{l}\text { Environmental } \\
\text { protection }\end{array}$ & -189.21671 & 64.085586* & $687.75362 * *$ & $2719.2665^{*}$ \\
\hline $\begin{array}{l}\text { General public } \\
\text { services }\end{array}$ & $-175.39309 *$ & $93.130823^{* * *}$ & $767.58383^{* * *}$ & 488.58557 \\
\hline Health & $-211.62969 *$ & $138.23541^{* * *}$ & $931.45833^{* * *}$ & 367.79626 \\
\hline $\begin{array}{l}\text { Housing and com- } \\
\text { munity amenities }\end{array}$ & -198.34762 & 52.156284 & 433.2957 & 1277.1841 \\
\hline $\begin{array}{l}\text { Recreation, culture } \\
\text { and religion }\end{array}$ & $-377.79483^{* * *}$ & $131.02147^{* * *}$ & $983.14901 * *$ & $2672.9281^{*}$ \\
\hline $\begin{array}{l}\text { Public order and } \\
\text { safety }\end{array}$ & (omitted) & (omitted) & (omitted) & (omitted) \\
\hline Social protection & $-194.66118^{* *}$ & $116.41929 * * *$ & $733.76937^{* * *}$ & -135.69369 \\
\hline _cons & $214.30992 * *$ & -20.521916 & $-633.9261 * *$ & 252.20826 \\
\hline $\mathrm{N}$ & 169 & 192 & 192 & 190 \\
\hline rho & .83079122 & .87842898 & .98742319 & .95772959 \\
\hline $\mathrm{r} 2$ & .11253524 & .65056168 & .22256833 & .35015324 \\
\hline r2_a & -.08827796 & .582858 & .07194095 & .22265166 \\
\hline
\end{tabular}

* significance level of 0.05 , ** significance level of $0.01, * * *$ significance level of 0.001

Panel studies for all European Union member states irrespective of the Maastricht deficit criterion revealed that the variable with a significant impact on the value of People at risk of poverty or social exclusion by age and sex was expenditure on Economic affairs, Education, Public order and safety, Health, Social protection, Recreation, culture and religion. For the countries with a fiscal deficit below 3\% of GDP, the model explains the variability of this indicator according to government spending at $11 \%$, while for other EU countries this indicator stood at $38 \%$. $83.08 \%$ 
of the variance (variability) of People at risk of poverty or social exclusion by age and sex stems from differences between panels (countries). "Rho" is known as an intraclass correlation. The results revealed that countries aiming to limit poverty should change the structure of expenditure according to the extent to which they wish to improve the value of People at risk of poverty or social exclusion by age and sex; in particular, the research demonstrated that:

- increasing the share of education spending by 1 percentage point (compared to the general expenditure) will cause the number of socially excluded people to decrease by $2.25 \%$ compared to the current situation;

- increasing the share of economic affairs spending by 1 percentage point (compared to the general expenditure) will cause the number of socially excluded people to decrease by $1.67 \%$ compared to the current situation;

- increasing the share of health spending by 1 percentage point (compared to the general expenditure) will cause the number of socially excluded people to decrease by $2.11 \%$ compared to the current situation;

- increasing the share of general public services spending by 1 percentage point (compared to the general expenditure) will cause the number of socially excluded people to decrease by $1.75 \%$ compared to the current situation.

In addition, another very interesting outcome of the research is the finding that government spending on housing and community amenities is a relatively ineffective tool for tackling poverty, as this amount does not affect the value of People at risk of poverty or social exclusion by age and sex.

For Life expectancy by age and sex, the scale of expenditure on environmental protection is of great significance: increasing its share by 1 percentage point (compared to general spending) will cause the Life expectancy indicator to grow by $0.64 \%$ compared to the current situation. The other spending categories show a relatively low correlation, e.g. general public services, health, recreation, culture and religion, or no correlation whatsoever with Life expectancy by age and sex is found.

In turn, the panel studies revealed that all COFOG spending categories except housing and community amenities are variables that have a significant impact on the Main GDP aggregates per capita. In particular, what contributes most to the growth of this indicator is a 1 percentage point increase (compared to general spending) in spending on economic affairs (up by $6.86 \%$ ), education (up by $8.43 \%$ ), environmental protection (up by $6.87 \%$ ), general public services (up by $7.67 \%$ ), and health (up by $9.31 \%$ ).

The situation is quite different for Municipal waste by the waste management operations (kilograms per capita), significantly affected by a 1 percentage point increase in environmental protection spending, which will result in this indicator growing by as much as $27.2 \%$.

In order to obtain full and reliable research results, models for sustainable development indicators were analyzed in detail, also by comparing the fixed effects and random effects panel models. 
Tab. 3 - Hausman tests for the models analyzed. Source: own research

\begin{tabular}{|l|l|l|l|l|}
\hline Detail & \multicolumn{2}{|l|}{$\begin{array}{l}\text { Models used to analyze countries } \\
\text { with fiscal deficit }>3 \% \text { of GDP }\end{array}$} & \multicolumn{2}{|l|}{$\begin{array}{l}\text { Models used to analyze countries } \\
\text { with fiscal deficit }<3 \% \text { of GDP }\end{array}$} \\
\hline & $\begin{array}{l}\text { Hausman test } \\
\text { statistic (p-value) }\end{array}$ & Model selected & $\begin{array}{l}\text { Hausman test } \\
\text { statistic (p-value) }\end{array}$ & Model selected \\
\hline $\begin{array}{l}\text { People at risk of } \\
\text { poverty or social } \\
\text { exclusion by age } \\
\text { and sex }\end{array}$ & $94.02(0.002)$ & Fixed-effects & $94.31(0.0002)$ & Fixed-effects \\
\hline $\begin{array}{l}\text { Life expectancy } \\
\text { by age and sex }\end{array}$ & $66.69(0.0827)$ & $\begin{array}{l}\text { Random- } \\
\text { effects }\end{array}$ & $145.15(\mathrm{p}<0.0001)$ & Fixed-effects \\
\hline $\begin{array}{l}\text { Main GDP } \\
\text { aggregates per } \\
\text { capita - Percent- } \\
\text { age of EU27 } \\
\text { (from 2019) }\end{array}$ & $92.41(0.0016)$ & Fixed-effects & $742.25(\mathrm{p}<0.0001)$ & Fixed-effects \\
\hline $\begin{array}{l}\text { Municipal waste } \\
\text { by waste man- } \\
\text { agement opera- } \\
\text { tions (kilograms } \\
\text { per capita) }\end{array}$ & $13.92(0.3060)$ & $\begin{array}{l}\text { Random- } \\
\text { effects }\end{array}$ & $62.54(\mathrm{p}<0.0001)$ & Fixed-effects \\
\hline
\end{tabular}

The results obtained demonstrated that in the countries with a fiscal deficit above $3 \%$ of GDP, for indicators such as Life expectancy by age and sex, and Municipal waste by waste management operations (kilograms per capita), the impact of independent variables on the dependent variable is unrelated to differences between countries, which is why random effects model estimations are equally as good as those for the fixed effects model. As such, a detailed analysis was conducted using the fixed effects model for those explanatory variables, not only in terms of the main spending category but also for subcategories. The results obtained demonstrated that within the COFOG categories, no individual subcategories clearly contributing to a change in the sustainable development indicators analyzed can be identified.

The implications of the growing public spending on economic growth are ambiguous, with some studies demonstrating that it can have a positive impact on sustainable development indicators, provided that fiscal deficit is kept under control. The direction and consequences of income redistribution by government, and especially in terms of public spending, vary depending on the adopted theory of economic growth. A positive impact of expenditure incurred from fiscal deficit is posited by the theory of effective demand, while a neutral or negative impact of expenditure on economic growth is indicated by the new neoclassical synthesis (Kiselakova et al., 2018). The above mentioned schools of economic thought represent a theoretical framework for the political choice between a greater dose of interventionism or liberalism. The model studies demonstrated that countries where fiscal deficit is below $3 \%$ of GDP can implement a sustainable development policy more effectively, thus promoting competitiveness, instead of the periodic shocks and budget cuts 
which accompany remedial processes and procedures to alleviate excessive deficits. This probably stems from the fact that when choosing the method of impact on the social and economic environment, authorities in the countries with a fiscal deficit below 3\% of GDP try to adapt as far as possible to the particular situation in the country, and to the sensitivity of sustainable development indicators in terms of respective components. This corroborates previous theoretical propositions indicating that by consistently building a stable fiscal policy in the long run, it is possible to optimize the outcomes obtained not only with support from government but also due to market mechanism operations, which run complementary to it. For the countries with excessive fiscal deficit, government spending in most cases does not contribute to the growth of sustainable development indicators; on the contrary, it has quite the opposite effect, destabilizing economic mechanisms.

It can be indicated that the present research falls under the parameters of EU institutional declarations and activities. Competitiveness has become officially one of the European Union's priorities since 2000 (Dobrovic et al., 2018). As described in the Europe 2020 strategy, sustainable growth needs to be achieved through high competitiveness and the green economy, i.e. imposing less demand for resources. This is confirmed by panel studies. Since the 1987 Brundtland Report, through 1992's UN Agenda 21, on to the World Summit on Sustainable Development in Johannesburg in 2002, the need for sustainable development has been demonstrated, its three main pillars being economy, society and environment.

Another document prepared and published by High-Level Expert Group (European Commission, 2018) maps out the challenges and opportunities that the EU faces in developing a sustainable finance policy. The report identifies ways in which the financial sector can re-connect with the real economy to support the transition to a more resource-efficient and more circular economy. The group argues that reorienting investment flows into long-term, sustainable projects will also improve the stability of the financial system. The document indicates the directions for action towards achieving durable and sustainable development based on efforts to combine economic welfare with environmental and social sustainability (Krejdl, 2006). However, as the study has shown, indicators for sustainable development goals diverge in individual countries, a situation which suggests that sustainability and competitiveness will be achieved by other means, and will be strongly dependent on the excessive deficit procedures undertaken in those countries to which it will be applied.

\section{CONCLUSIONS}

This research indicates that fiscal authorities should factor in the specific effect of the duration and level of fiscal imbalance in the public sector when taking decisions affecting the size and structure of spending, otherwise the effectiveness of these measures is greatly limited. We are dealing with the phenomenon of a lag between fiscal decisions and their consequences for economic processes and growth dynamics. Sustainable development means "better development" and "better finance" - development that is sustainable in all of its economic and social aspects, along with stable public finance. Such development also needs to address issues related to competitiveness as an essential condition towards the achievement of sustainable development. In this context, the challenge facing the contemporary world, and especially European Union mem- 
ber states, is an even more efficient allocation of available resources to ensure they bring the best possible result, not only in the sense of increasing GDP but also - or maybe even first and foremost - in terms of raising the standard of living for all citizens. Such an approach is necessary to maintain the competitive advantages of living in certain countries, especially in the era of limited resources along with the aging society in Europe.

Certain postulates in the literature enable the measurement of the factors responsible for social development more widely than was possible in years past. The measurement of development is carried out not only with the help of the GCI, the indicator measuring competitiveness, but also with the help of the HDI, an indicator for human development. This human-centered approach is all the more justified in that according to the research results economic growth has a positive relationship with HDI in the long term. Regardless of above mentioned tools for measuring competitiveness, there are demands for the integration of a greater number of diverse economic, social and innovation areas in terms of analyzing the growth potential of individual countries. These types of analyses should also be extended to two other indices, the global innovation index (GII) and the economic freedom index (EFI).

\section{References}

1. Abramov, R. A., Mukhaev, R. T., \& Sokolov, M.S. (2016). To a Question about the Criteria and Parameters of the Effectiveness of the Government in Democratic Countries. Journal of Advanced Research in Law and Economics, 7 (6), 1248-1262. https://doi.org/:10.14505/jarle. v7.6(20).01

2. Alegre, J. G. (2012). An Evaluation of EU Regional Policy. Do Structural Actions Crowd Out Public Spending? Public Choice, 151 (2), 1-21. https://doi.org/10.1007/s11127-010-9731-5

3. Arrow, K. J. (2013). Economic Theory and the Financial Crisis. Procedia Social and Behavioral Sciences, 77 (5), 5-9.

4. Artidiatun, A. (2017). Stigler's influential contribution to economic thought. Journal of Indonesian Economy and Business, 32 (1), 70-80. https://doi.org/10.22146/jieb.22981

5. Balkyte, A., \& Tvaronavičiene, M. (2010). Perception of competitiveness in the context of sustainable development: Facets of sustainable competitiveness. Journal of Business Economics and Management, 11 (2), 341-365. https://doi.org/10.3846/jbem.2010.17

6. Becker, G. S. (2015). Perfect Competition. Managerial Economics, 8 (1), 3-4. https://doi. org/10.1002/9781118785317.weom080041

7. Bermard, P., \& Guillaume, B. (2007). Institutional competitiveness, social investment, and welfare regimes. Regulation \& Governance, 1 (3), 213-229. https://onlinelibrary.wiley.com/ doi/full/10.1111/j.1748-5991.2007.00016.x

8. Bock, K. (2017). European Competitiveness and Industry. European Competitiveness Working Group Report, 24-28.

9. Breton, A. (1996). Competitive governments. An economic theory of politics and public finance. New York: Cambridge University Press. 
10. Buch, C., \& Dages, B.G. (ed.) (2018). Structural changes in banking after the crisis. Working Group established by the Committee on the Global Financial System, Bank for International Settlement. CGFS Papers, 60, 1-119.

11. Buchholz, W. (2016). Olson's exploitation hypothesis in a public good economy: a reconsideration, Public Choice, 168 (1-2), 103-114.

12. Collignon, S. (2008). The Lisbon Strategy, Macroeconomic Stability and the Dilemma of Governance with Governments; or why Europe is not Becoming the World's Most Dynamic Economy. International Journal of Public Policy, 3 (1-2), 72-99. https://doi. org/10.1504/IJPP.2008.017127

13. Davidson, R. (2017). Crisis Neoliberalism and Regimes of Permanent Exception. Critical Sociology, 43 (4-5), 615-634. https://doi.org/10.1177/0896920516655386

14. Dima, A. M., Begu, L., Vasilescu, M. D., \& Maassen, M. A. (2018). The relationship between the Knowledge Economy and Global Competitiveness in the European Union. Sustainability, 10 (1706), 1-15. https://doi.org/10.3390/su10061706

15. Dobrovic, J., Gallo, P., Mihalcova, B., Stofova, L., \& Szaryszova, P. (2018). Competitiveness measurement in terms of the Europe 2020 strategy. Journal of Competitiveness, 10 (4). https:// doi.org/10.7441/joc.2018.04.02

16. Donaires, O. S, Cezarino, L. O., Caldana, A. C. F., \& Liboni, L. (2019). Sustainable development goals - an analysis of outcomes. Kybernetes, 48 (1), 183-207. https://doi. org/10.1108/K-10-2017-0401

17. Elkington, J. (2004). Enter the Triple Bottom Line. Open Journal of Civil Engineering, 6 (5).

18. Erhard, L. (2012). Prosperity Through Competition. New York: Kindle Edition, 11-35.

19. European Commission (2018). Financing a European economy, Final Report 2018 by the High-Level Expert Group on Sustainable Finance Secretariat provided by the European Commission

20. Facchini, F., \& Seghezza, E. (2018). Public Spending Structure, Minimal State and Economic Growth in France (1870-2010). Economic Modelling, 72, 151-164. https://doi. org/10.1016/j.econmod.2018.01.014

21. Fama, E. F., \& French, K. R. A. (2014). Five-Factor Asset Pricing Model. Fama-Miller Working Paper. https://ssrn.com/abstract $=2287202$

22. Fleming, J. (1962), Domestic Financial Policies Under Fixed and Under Floating Exchange Rates, IMF Staff Papers, 12, 369-80.

23. Friedman B.M. (2005). The Moral Consequences of Economic Growth. Alfred A. Knopf, New York.

24. Gorynia, M., \& Kowalski, T. (2008). Globalne i krajowe uwarunkowania funkcjonowania polskich przedsiębiorstw. Ekonomista, 1, 51-77.

25. Hoover, K. D. (2015). The Crisis in Economic Theory: A Review Essay, The Center for the History of Political Economy Working Paper. https://ssrn.com/abstract=2688159 
26. Kiselakova, D., Sofrankova, B., Cabinova, V., Onuferova, E., \& Soltesova, J. (2018). The Impact of R\&D Expenditure on the Development of Global Competitiveness within the CEE EU Countries. Journal of Competitiveness, 10 (3), 34-50. https://doi.org/10.7441/ joc. 2018.03 .03

27. Ivanová, E., \& Čepel, M. (2018). The Impact of Innovation Performance on the Competitiveness of the Visegrad 4 Countries. Journal of Competitiveness, 10 (1), 54-72. https:// doi.org/10.24136/oc.2018.030

28. Kiesiel’áková, D., Šofranková, B., Gombár, M., Čabinová, V., \& Onuferová E. (2019). Competitiveness and Its Impact on Sustainability, Business Environment, and Human Development of EU (28) Countries in terms of Global Multi-Criteria Indices. Sustainability, 11 (12), 1-25. https://doi.org/10.3390/su11123365

29. Krejdl, A. (2006). Fiscal Sustainability - Definition, Indicators and Assessment of Czech Public Finance Stability. Czech National Bank, Working Paper Series, 3. https://www.cnb. cz/en/research/research_publications/cnb_wp/download/cnbwp_2006_03.pdf.

30. Mazzucato, M. (2018). The Entrepreneurial State: debunking public vs. private sector myths. Penguin, London.

31. Mundell, R. (1963). Capital Mobility and Stabilization Policy Under Fixed and Flexible Exchange Rates. Canadian Journal of Economics and Political Science, 29 (4), 475-485.

32. Nurse, K. (2006). Culture as the fourth pillar of sustainable development, Small States: Economic. Marlborough House, London.

33. OECD (2015). Competitiveness policy: A new agenda, DSTI/IND (95) 14, Paris.

34. Oprescu, R. (2012). Bridging intellectual capital and the competitiveness of nations. Management \& Marketing Challenges for the Knowledge Society, 7 (1), 73-88.

35. Patora-Wysocka, Z., \& Sułkowski, Ł. (2019). Sustainable Incremental Organizational Change - A Case of the Textile and Apparel Industry. Sustainability, 11 (4), 1-27. https://doi. $\operatorname{org} / 10.3390 /$ su11041102

36. Postula, M. (2018). Ten Years of Performance Budget Implementation in Poland - Successes, Failures, Future. In ed. Lotko, E, Zawadzka-Pak, U. K., Radvan, M. Optimization of Organization and Legal Solutions concerning Public Revenues and Expenditures in Public Interest. Temida 2, Bialystok-Vilnius, 243-261.

37. Pretorius, C., \& Pretorius, N. (2016). Public Financial Management. Reform Literature Review, Department for International Development, Evaluation Report EV698, London.

38. Raczkowski, K. (2014). Intellectual capital management in tax administration and country's economic growth determined by competitive taxation. In: Raczkowski, K., Sułkowski, Ł. Tax Management and Tax Evasion, Peter Lang, Frankfurt am Main, 45-56.

39. Raczkowski, K. (2015). Public Management. Theory and Practice, New York: Springer.

40. Radło, M. J. (2008). Międzynarodowa konkurencyjność gospodarki. Uwagi na temat definicji, czynników i miar. Szkoła Główna Handlowa, Warsaw. 
41. Rambarran, R. (2015). Crisis without End: Neoliberalism In Globalized Environment Modeling the Historic Rise of Neoliberalism and its Systematic Role in Recent Economic Downturns. Review and Basic Statistics, 11 (1), 28-40.

42. Rodrik, D. (2007). One Economics, Many Recipes Globalization, Institutions, and Economic Growth. New Jersey: Princeton University Press.

43. Schwab, K. (2018). The Global Competitiveness Report. World Economic Forum. Available at http://www3.weforum.org/docs/GCR2018/05FullReport/TheGlobalCompeti tivenessReport2018.pdf

44. Shrithongrung, A., \& Kriz, K. A. (2014). The Impact of Subnational Fiscal Policies on Economic Growth: A Dynamic Analysis Approach. Journal of Policy Analysis and Management, 33 (4). https://doi.org/10.1002/pam.21784

45. Simionescu, M. (2016). Competitiveness and Economic Growth in Romanian Regions. Journal of Competitiveness, 8 (4), 46-60. https://doi.org/10.24136/oc.2019.019

46. Soini, K., \& Birkeland, I. (2014). Exploring the scientific discourse on cultural sustainability. Journal Norsk GeografiskTidsskrift - Norwegian Journal of Geography, 71 (3), 127-31. https://doi.org/10.1080/00291951.2017.1343381

47. Stiglitz, J. E. (2000). Economics of the Public Sector. New York: W. W. Norton.

48. Stiglitz, J. E. (2003). Globalization and its Discontents. New York: W. W. Norton.

49. Tudose, M. B, \& Rusu, V. D. (2015). Global Competitiveness of the European Union Member States: Evolution and Perspectives, Studies and Scientific Researches. Economic Edition. 22 (1), 23-31.

50. Wolf, M. (2004). Why Globalization Works. London: Yale University Press.

\section{Contact information}

prof. Marta Postuła, Ph.D.

Warsaw University

Faculty of Management

Poland

E-mail:mpostula@w:uw.edu.pl

ORCID:0000-0001-5502-9722

prof. Konrad Raczkowski, Ph.D.

University of Social Sciences

Institute of Economics

Poland

E-mail:rac₹kowski.konrad@gmail.com

ORCID: 0000-0002-8546-2647 